\title{
Effects of olive leaf extract and vitamin E supplementation in quail diet on some blood parameters and egg yolk fatty acids composition
}

\author{
Ayhan ÖZDEMIR ${ }^{1}$, Mehmet Ali AZMAN ${ }^{2}$ \\ ${ }^{1}$ Bingöl Directorate of Provincial Food Agriculture and Livestock, Bingöl; ${ }^{2}$ University of Firat, Faculty of Veterinary Medicine, \\ Department of Animal Nutrition and Nutritional Diseases, Elazı $\breve{g}$, Turkey.
}

\begin{abstract}
Summary: This experiment was performed to investigate the effect of dietary supplementation with olive leaf extract on some blood parameters and egg yolk fatty acid composition of laying quails. A total of 192 Japanese quail (Coturnix coturnix japonica) $60 \mathrm{~d}$ old were allocated to 4 treatment groups with 4 replicates each containing 12 birds. Birds housed in cages and water and feed were given ad libitum during the total period of experiment. The quails received a basal diet (maize and soyabean meal based; $19.1 \% \mathrm{CP}, 2.940 \mathrm{kcal} / \mathrm{kg} \mathrm{ME}, 3.0 \% \mathrm{Ca}$ and $0.39 \% \mathrm{P}$ av) that was formulated including vitamins and minerals. Diets were prepared as control (basal diet, group Control), basal diet plus $200 \mathrm{mg} \alpha$-tocopherol acetat $/ \mathrm{kg}$ (group E), and basal diet plus 80 or 120 ppm Oleuropein (OLE) (group OLE-80 and OLE-120). At the end of the experiment, egg yolks samples were analysed; cholesterol levels of groups fed diets with OLE- 80 and OLE-120 were significantly higher than the groups fed control diet $(\mathrm{p}<0.01)$; vitamin A levels of groups fed diets with vit. E were significantly lower than the groups fed control diet and containing OLE- $80(\mathrm{p}<0.05)$ and vitamin $\mathrm{E}$ levels were significantly higher than the other groups $(\mathrm{p}<0.001)$. The supplementation of olive leaf extract were influenced to fatty acid composition of egg yolk lipids. The concentration of oleic and linoleic acids in egg yolks were higher in OLE-80 than the others groups $(p<0.05)$. The concentration of PUFA, $n-6$ fatty acids and $n-6 / n-3$ fatty acids ratio were the highest in OLE- 80 groups than the other groups. These results showed that the supplementation of $80 \mathrm{ppm}$ OLE in quail diets was conducted to increase of oleic, linoleic and $\mathrm{n}-6$ fatty acids, and n-6/n-3 fatty acids ratio in egg yolks.
\end{abstract}

Key words: Blood parameters, egg yolk fatty acids, olive leaf extract, quail, vitamin E.

\section{Bıldırcın rasyonlarına zeytin yaprağı özütü ve E vitamini katılmasının bazı kan parametreleri ve yumurta sarısı yağ asitleri kompozisyonu üzerine etkileri}

Özet: Bu araştırma, bıldırcın karma yemlerine zeytin yaprağı özütü (ZYÖ) katılmasının kimi kan parametreleri ile yumurta sarısı yağ asitleri üzerine etkilerini belirlemek üzere planlandı. Bu amaçla 60 günlük yaşta toplam 192 adet dişi bildırcın (Coturnix Coturnix Japanica), her grupta 4 alt grup ve her alt grupta 12 bıldırcın olacak şekilde 4 deneme grubuna ayrıldı. Bildırcınlar deneme süresince kafeste barındırıldı, yem ve su serbest olarak verildi. Bildırcınlara mısır ve soya küspesine dayalı temel yem (\%19.1 HP, $2940 \mathrm{kcal} / \mathrm{kg} \mathrm{ME}, \% 3.0 \mathrm{Ca}$ ve \% 0.39 kullanılabilir P) vitamin ve mineral karıştırılarak hazırlandı. Bu yemi tüketen grup Kontrol, temel yeme $200 \mathrm{ppm} \alpha$-tokoferol asetat katılan grup (Grup E), 80 ve $120 \mathrm{ppm}$ Oleuropein (OLE) olacak şekilde ZYÖ katılan gruplar OLE-80 ve OLE-120 gruplarını oluşturdu. Deneme sonunda alınan yumurta sarısı örneklerinde, OLE-80 ve OLE-120 diyetleri tüketen gruplarda kolesterol düzeyi kontrol grubuna göre daha yüksek bulunurken $(\mathrm{p}<0.01)$; E vitamini katılan diyetleri tüketen grupta A vitamini düzeyi, kontrol ve OLE-80 gruplarına göre önemli düzeyde düşük ( $(<0.05)$, E vitamini düzeyi ise diğer gruplara göre önemli düzeyde yüksek bulunmuştur $(\mathrm{p}<0.001)$. Karma yemlere ZYÖ katılması yumurta sarısı yağ asitlerini etkilemiştir. OLE80 grubunun yumurta sarısı oleik ve linoleik asit düzeyleri diğer gruplardan daha yüksek bulunmuştur $(p<0.05)$. OLE- 80 grubunun yumurta sarısı PUFA, n-6 yağ asitleri ve n-6/n-3 yağ asidi oranı diğer gruplardan daha yüksek bulunmuş̧ur. Bu sonuçlara göre, bıldırcın karma yemlerine 80 ppm OLE katılması, yumurta sarısı oleik, linoleik ve $n-6$ yağ asitleri ile n-6/n-3 yağ asidi oranını artırmıştır.

Anahtar sözcükler: Bıldırcın, E vitamini, kan parametreleri, yumurta sarısı yağ asitleri, zeytin yaprağı özütü.

\section{Introduction}

One of the many waste by-products used nowadays is the olive leaf which is obtained during the harvesting of the olives, the pruning of olive trees or the cleaning procedures before the extraction of the olive oil. Depending on conditions, approximately 12-30 kilograms of leaf is obtained from each olive tree yearly $(6,12)$.
It has been reported that the world's annual olives production is approximately 13 million tons. In this production, Turkey has a significant share of $9 \%$ (8).

The olive itself and its leaves are rich in phenolic glycosides such as oleuropein (OLE), verbascocide and ligrocide; flavanoids, flavonol glycosides, anthocyanins and glycosides, as well as phenolic compounds such as 
phenolic acid (17, 25). Phenolic compounds are important not only because of their antioxidant and antimicrobial properties, but also contribution to the oxidative stability and the sensorial properties $(14,25)$.

Erener et al. (13) was found $112.98 \mathrm{mg}$ of OLE, $34.45 \mathrm{mg}$ of rutin, $16.67 \mathrm{mg}$ of hydroxytyrosol, $7.33 \mathrm{mg}$ of vanillin, $4.68 \mathrm{mg}$ of vanillic acid, $4.42 \mathrm{mg}$ of caffeic acid, $1.68 \mathrm{mg}$ concentration of catechin, and had an antioxidant capacity of EC50 $19.54 \mu \mathrm{l}$ in the olive leaf exract. Visioli and Galli, (31) found the phenolic compound ingredient of the olive to be between 50 and $800 \mathrm{mg} / \mathrm{kg}$. Vinha et al. (30) found that the dry samples of olive fruits contained 388-21681 mg/kg of OLE, 1477$15763 \mathrm{mg} / \mathrm{kg}$ of hydroxytyrosol, $174 \mathrm{mg} / \mathrm{kg}$ of verbascocide and $12.5 \mathrm{mg} / \mathrm{kg}$ of 5 -coffee oil quinic acid.

It has been reported that hydroxytyrosol, a main bioactive metabolite of OLE, is a strong naturally occurring antioxidant; and elenolic acid, another structural sub unit, has strong antiviral properties (26, 27).In the United States it has been reported that OLE has antiviral activities against mononucleosis herpes, hepatitis viruses, rotaviruses, bovine viruses, parvoviruses in dogs and leukemia viruses in cats, and has anti-HIV properties $(5,20,21)$.

Akçiçek and Otleş (1) have mentioned that the olive leaf extract included 19\% OLE, $1.8 \%$ flavonoid glycosides and 3-4 dihydroxy-phenethyl esters, that various phenolic compounds within olive leaves possess preventive effects against oxidation of LDL cholesterol, and that OLE has stronger antioxidant properties than BHT, vitamin $\mathrm{C}$ and vitamin $\mathrm{E}$.

The aim of this study was to investigate the effects of olive leaf extract supplementation to quail ration on some blood serum levels and egg yolk cholesterol and fatty acids composition.

Table 1. Ingredients and nutrient composition of diets (\%).

Tablo 1. Rasyonların bileşimi ve besin madde içerikleri (\%).

\begin{tabular}{|c|c|c|c|c|}
\hline Ingredients & Control & $\begin{array}{l}\text { Vit. E } \\
\text { group }\end{array}$ & $\begin{array}{l}\text { OLE-80 } \\
\text { group }\end{array}$ & $\begin{array}{l}\text { OLE-120 } \\
\text { group }\end{array}$ \\
\hline Corn & 50 & 50 & 50 & 50 \\
\hline Soybean meal (\% $48 \mathrm{CP})$ & 29 & 29 & 29 & 29 \\
\hline Wheat bran & 7 & 7 & 7 & 7 \\
\hline Soybean oil & 2.5 & 2.5 & 2.5 & 2.5 \\
\hline Flaxseed oil & 2.5 & 2.5 & 2.5 & 2.5 \\
\hline Dicalcium phosphate & 1.7 & 1.7 & 1.7 & 1.7 \\
\hline Limestone & 6.5 & 6.5 & 6.5 & 6.5 \\
\hline Salt & 0.35 & 0.35 & 0.35 & 0.35 \\
\hline Vit. + Min. premix* & 0.30 & 0.30 & 0.30 & 0.30 \\
\hline Vitamin E (mg/kg) & - & 167.3 & - & - \\
\hline Olive leaf extract $(\mathrm{g} / \mathrm{kg})$ & - & - & 1.2 & 1.8 \\
\hline \multicolumn{5}{|l|}{ Analysis } \\
\hline $\mathrm{CP} \% * *$ & 19.1 & 19.1 & 19.1 & 19.1 \\
\hline $\mathrm{ME}, \mathrm{kcal} / \mathrm{kg} * * *$ & 2940 & 2940 & 2940 & 2940 \\
\hline $\mathrm{Ca}, \% * * *$ & 3.0 & 3.0 & 3.0 & 3.0 \\
\hline $\mathrm{P}$ av.\%*** & 0.39 & 0.39 & 0.39 & 0.39 \\
\hline Vitamin E $(\mathrm{mg} / \mathrm{kg}) * *$ & 32.7 & 200 & 32.7 & 32.7 \\
\hline Meth+systine, \% & 0.70 & 0.70 & 0.70 & 0.70 \\
\hline Lysine, \% & 1.03 & 1.03 & 1.03 & 1.03 \\
\hline
\end{tabular}

* Vitamin premix supplied per $2.5 \mathrm{~kg}$; vitamin A, $12.000 .000 \mathrm{IU}$; vitamin $\mathrm{D}_{3}, 2.000 .000 \mathrm{IU}$; vitamin E $32.700 \mathrm{mg}$; vitamin $\mathrm{K}_{3}, 4.000$ mg; vitamin $B_{1} 3.000 \mathrm{mg}$; vitamin $B_{2} 7.000 \mathrm{mg}$; niacin $20.000 \mathrm{mg}$; calcium panthothenate, $10.000 \mathrm{mg}$; vitamin $B_{6} 5.000 \mathrm{mg}$; vitamin $\mathrm{B}_{12} 15 \mathrm{mg}$; folic acid $1.000 \mathrm{mg}$; D-Biotin $45 \mathrm{mg}$; vitamin C $50.000 \mathrm{mg}$; choline chloride $125.000 \mathrm{mg}$; canthaxanthin 2.500 $\mathrm{mg}$; Apo carotenoid acid ester $500 \mathrm{mg}$.

* Mineral premix supplied per kg; Mn 80.000 mg; Fe 60.000 mg; Zn 60.000 mg; Cu 5.000 mg; Co 200 mg; I 1.000 mg; Se 150 mg.

** Analysis,

*** Calculation $(\mathrm{ME}(\mathrm{kcal} / \mathrm{kg})=(37,07 \mathrm{CP} \%)+(82 \mathrm{CF} \%)+(39.89 \operatorname{starch} \%)+(31.1 \operatorname{sugar} \%))$.

* Her $2.5 \mathrm{~kg}$ vitamin premiksinde ; A vitamini, 12.000.000 IU; $\mathrm{D}_{3}$ vitamini, 2.000.000 IU; E vitamini $32.700 \mathrm{mg}$; $\mathrm{K}_{3}$ vitamini, 4.000 $\mathrm{mg}$; $\mathrm{B}_{1}$ vitamini $3.000 \mathrm{mg}$; $\mathrm{B}_{2}$ vitamini $7.000 \mathrm{mg}$; niyasin $20.000 \mathrm{mg}$; kalsiyum pentatonat, $10.000 \mathrm{mg} ; \mathrm{B}_{6}$ vitamini $5.000 \mathrm{mg} ; \mathrm{B}_{12}$ vitamin $15 \mathrm{mg}$; folik asit $1.000 \mathrm{mg}$; D-Biyotin $45 \mathrm{mg}$; C vitamini $50.000 \mathrm{mg}$; kolin klotrit $125.000 \mathrm{mg}$; kantaksantin $2.500 \mathrm{mg}$; Apo karotenoid asit ester $500 \mathrm{mg}$.

* Her 1 kg mineral premiksinde; Mn 80.000 mg; Fe 60.000 mg; Zn 60.000 mg; Cu 5.000 mg; Co 200 mg; I 1.000 mg; Se 150 mg.

** Analiz yoluyla bulunmuştur.

*** Hesaplama $(\mathrm{ME}(\mathrm{kcal} / \mathrm{kg})=(37,07 \mathrm{HP} \%)+(82 \mathrm{HY} \%)+(39.89$ Nişasta\% $)+(31.1$ Şeker\% $))$. 


\section{Material and Methods}

Animals, diets and feeding: In this study, a total of 192 female, 60-day old quails (Coturnix Coturnix Japonica) were obtained from Bingol University Faculty of Agriculture, were used after Firat University Animal Ethical Committee approval (Official form date and number: 20.01.2011 and 2011/16) and divided into 4 groups of 48 quails each. The feeding material of the study included corn and soybean meal based diets as presented in Table 1. The control group was fed the basic diet, group $\mathrm{E}$ received basic diet added with vitamin $\mathrm{E}$ (200 ppm), groups OLE-80 and OLE-120 received basic diet added with 80 and $120 \mathrm{ppm}$ of Oleuropein, respectively. Vitamin $\mathrm{E}$ and olive leaf extract used as the source of oleuropein were obtained from a private company. The vitamin E level of the basic diet used in the study was determined and $\alpha$-tocopherol acetate was added to obtain a total of $200 \mathrm{ppm}$. The composition of the fatty acids in olive leaf extract were shown Table 2.

Table 2. The Fatty acid composition of the olive leaf extract, $\mu \mathrm{g} / \mathrm{g}$ extract.

Tablo 2. Zeytin yaprağı özütünün yağ asidi kompozisyonu, $\mu \mathrm{g} / \mathrm{g}$ özüt.

\begin{tabular}{lc}
\hline Fatty acids & $\mu \mathrm{g} / \mathrm{g}$ extract. \\
\hline $\mathrm{C} 14: 0$ & 55.0 \\
$\mathrm{C} 16: 0$ & 1090 \\
$\mathrm{C} 16: 1 \mathrm{n} 7$ & 148 \\
$\mathrm{C} 18: 0$ & 160 \\
$\mathrm{C} 18: 1 \mathrm{n} 9 \mathrm{c}$ & 456 \\
$\mathrm{C} 18: 2 \mathrm{n} 6 \mathrm{t}$ & 28 \\
$\mathrm{C} 18: 2 \mathrm{n} 6 \mathrm{c}$ & 206 \\
$\mathrm{C} 18: 3 \mathrm{n} 3$ & 382 \\
$\mathrm{C} 20: 0$ & 27 \\
$\mathrm{C} 20: 5 \mathrm{n} 3$ & 58 \\
C24:0 & 115 \\
$*$ SFA & 1447 \\
$* *$ MUFA & 604 \\
$* * * P U F A$ & 674 \\
PUFA / SFA & 0.466 \\
$\mathrm{n}-6$ & 234 \\
$\mathrm{n}-3$ & 440 \\
Ratio n-6/n-3 & 0.532 \\
\hline
\end{tabular}

*SFA: saturated fatty acid, **MUFA: monounsaturated fatty acid, ***PUFA: polyunsaturated fatty acid.

*SFA: doymuş yağ asitleri, **MUFA: tekli doymamış yağ asitleri, ***PUFA: çoklu doymamış yağ asitleri.

Birds were weighed at the beginning of the study and randomly assigned to groups each containing 48 and 4 replicates containing 12 quail each. Feed and water given ad libitum for 42 days. The trail room was kept at a constant temperature of $20-23{ }^{\circ} \mathrm{C}$ and lighting was used to create a 16 to 8 hour ratio of light to dark program. For the egg yolk analysis, all eggs laid on the $42^{\text {nd }}$ day were collected, based on the average egg weight 6 eggs were selected from each group. The egg yolks were separated, and kept at $-20{ }^{\circ} \mathrm{C}$ until analysis.

At the end of the study, 6 birds with the weights close to the group average were randomly selected, killed by cervical dislocation and blood samples were collected. Serum separation was performed via 9 minutes of centrifugation at $3000 \mathrm{rpm}$, and serum samples were stored at $-20^{\circ} \mathrm{C}$ until the analysis.

Using a biochemical autoanalyser (Olimpus AU600) blood glucose, cholesterol, triglyceride, HDL, VLDL and LDL levels were determined. Chemical analyses: Dry matter, crude ash, crude protein and crude fat levels of the diet samples were determined according to AOAC procedures (2), whereas crude fiber level were determined according to Crampton and Maynard (10).

The olive leaf extract used in the study was provided from private firm (the Natural Products Research and Development Ltd. (DUAG), IzmirTürkey). The OLE content in the extract was determined in the Herbal Drugs and Scientific Research Center of Eskisehir Anadolu Universtiy using HPLC instrument. The result of analysis of the olive leaf extract was 7,9\% oleuropein Lipid extraction from egg samples was performed the Hara and Radin (16) method where 3:2 (v/v) hexane: isopropanol mixture is used. The levels of vitamins $\mathrm{A}, \mathrm{D}, \mathrm{E}$ and $\mathrm{K}$, and cholesterol of the egg yolks were analysed with the HPLC instrument (Shimadzu, Kyota Japan) (22).

The egg yolk fatty acids were analysed with gas chromatography (by Shimadzu GC 17) following the transformation of the fatty acids within the lipid extracts into their methyl esters. $\mathrm{SP}^{\mathrm{TM}}-2380$ capillary GC column $\left(\mathrm{L} \times\right.$ I.D. $\left.30 \mathrm{~m} \times 0.25 \mathrm{~mm}, \mathrm{~d}_{\mathrm{f}} 0.20 \mu \mathrm{m}\right)$ (Supelco, Sigma, USA) was used for this analysis $(9,29)$.

Statistical analyses: The SPSS 15.0 software program was used for the statistical analyses (SPSS, 2002). One-Way Anova test was used for the comparison of the groups. Duncan multiple comparison test was used for the differences between groups. The chi-square test was utilised to determine the differences between death rates of the study groups.

\section{Results}

The levels of serum glucose, cholesterol and triglyceride in the hens fed vit. E, OLE 80 or OLE 120 groups were not significantly different from that of the hens fed control diet ( $p>0.05)$. Concentration of HDL cholesterol, VLDL cholesterol and LDL cholesterol were not affected by the experimental diets (Table 3). The egg yolk concentrations of total cholesterol, vitamin A, vitamin E, vitamin D2 and D3 are shown in Table 4. The highest cholesterol level was found in the groups fed with OLE-80 and OLE-120 than birds fed control diets 
Table 3. Blood serum glucose, cholesterol and triglyseride levels in experimental groups (mg/dl) (Mean $\pm \mathrm{SE})$. Tablo 3. Deneme gruplarında kan serumu glikoz, kolesterol ve trigliserit düzeyleri (mg/dl) (Ortalama \pm SE).

\begin{tabular}{lccccc}
\hline & Control & Vit. E group & OLE-80 group & OLE-120 group & P \\
\hline Glucose & $181 \pm 7.6$ & $279 \pm 18.0$ & $302 \pm 13.1$ & $281 \pm 36.8$ & 0.820 \\
Cholesterol & $161 \pm 11.4$ & $143 \pm 12.0$ & $163 \pm 17.1$ & $225 \pm 37.3$ & 0.061 \\
HDL Cholesterol & $68.1 \pm 4.6$ & $63.5 \pm 4.2$ & $70.5 \pm 6.4$ & $113 \pm 30.2$ & 0.077 \\
VLDL Cholesterol & $135 \pm 28.1$ & $165 \pm 20.4$ & $152 \pm 15.8$ & $185 \pm 36.1$ & 0.584 \\
LDL Cholesterol & $67.9 \pm 8.8$ & $49.7 \pm 2.9$ & $51.8 \pm 3.9$ & $57.0 \pm 11.7$ & 0.300 \\
Triglyceride & $675 \pm 140$ & $823 \pm 102$ & $761 \pm 78.9$ & $927 \pm 180$ & 0.585 \\
\hline
\end{tabular}

Table 4. Cholesterol and certain vitamin in egg yolk in experimental groups ( $\mu \mathrm{g} / \mathrm{g}$ egg yolks) (Mean $\pm \mathrm{SE}$ ).

Tablo 4. Deneme gruplarında yumurta sarısı kolesterol ve bazı vitamin düzeyleri ( $\mu \mathrm{g} / \mathrm{g}$ yumurta sarıs1) (Ortalama $\pm \mathrm{SE})$.

\begin{tabular}{lccccc}
\hline Besin maddeleri & Control & Vit. E group & OLE-80 group & OLE-120 group & P \\
\hline Cholesterol & $10.4 \pm 0.74^{\mathrm{b}}$ & $12.1 \pm 0.51^{\mathrm{a}}$ & $13.1 \pm 0.68^{\mathrm{a}}$ & $13.3 \pm 0.35^{\mathrm{a}}$ & 0.010 \\
Vitamin A & $0.11 \pm 0.01^{\mathrm{a}}$ & $0.06 \pm 0.02^{\mathrm{b}}$ & $0.13 \pm 0.01^{\mathrm{a}}$ & $0.10 \pm 0.02^{\mathrm{ab}}$ & 0.029 \\
Vitamin E & $0.95 \pm 0.17^{\mathrm{b}}$ & $3.32 \pm 0.14^{\mathrm{a}}$ & $1.13 \pm 0.12^{\mathrm{b}}$ & $1.32 \pm 0.14^{\mathrm{b}}$ & 0.000 \\
${\text { Vitamin } \mathrm{D}_{2}}^{\mathrm{b}}$ & $0.07 \pm 0.02$ & $0.07 \pm 0.01$ & $0.07 \pm 0.01$ & $0.09 \pm 0.01$ & 0.686 \\
${\text { Vitamin } \mathrm{D}_{3}}_{\text {Stigmasterol }}^{0.03 \pm 0.00}$ & $0.02 \pm 0.00$ & $0.02 \pm 0.00$ & $0.02 \pm 0.00$ & 0.183 \\
\hline
\end{tabular}

a,b: Means with different letters in the same line are different by Duncan's test $(\mathrm{p}<0.05)$.

a,b: Aynı satırda farklı harf taşıyan değerler Duncan testine göre farklıdır $(\mathrm{p}<0.05)$.

Table 5. Olive leaves extract or $\alpha$-tocopheryl acetate on the fatty acid composition of egg yolks $\mu \mathrm{g} / \mathrm{g}$ (Mean $\pm \mathrm{SE}$ ).

Tablo 5. Zeytin yaprağı özütü veya $\alpha$-tokoferol asetatın yumurta sarısı yağ asidi kompozisyonu üzerine etkileri, $\mu \mathrm{g} / \mathrm{g}$ (Ortalama $\pm \mathrm{SE}$ ).

\begin{tabular}{lccccc}
\hline Fatty acids & Control & $\begin{array}{c}\text { Vit. E } \\
\text { group }\end{array}$ & $\begin{array}{c}\text { OLE-80 } \\
\text { group }\end{array}$ & $\begin{array}{c}\text { OLE-120 } \\
\text { group }\end{array}$ & $P$ \\
\hline C14:0 & $0.00 \pm 0.00$ & $0.01 \pm 0.01$ & $0.06 \pm 0.02$ & $0.03 \pm 0.03$ & 0.151 \\
C15:1 & $0.02 \pm 0.00$ & $0.02 \pm 0.00$ & $0.01 \pm 0.00$ & $0.01 \pm 0.00$ & 0.179 \\
C16:0 & $2.55 \pm 0.56$ & $3.25 \pm 0.56$ & $5.69 \pm 0.93$ & $3.64 \pm 1.09$ & 0.073 \\
C16:1n7 & $0.20 \pm 0.05$ & $3.26 \pm 2.75$ & $0.73 \pm 0.17$ & $0.69 \pm 0.30$ & 0.418 \\
C17:0 & $0.00 \pm 0.00$ & $0.01 \pm 0.01$ & $0.03 \pm 0.01$ & $0.02 \pm 0.01$ & 0.081 \\
C17:1 & $0.26 \pm 0.06$ & $0.32 \pm 0.04$ & $0.27 \pm 0.04$ & $0.27 \pm 0.06$ & 0.708 \\
C18:0 & $1.87 \pm 0.39$ & $2.24 \pm 0.18$ & $2.25 \pm 0.28$ & $1.72 \pm 0.58$ & 0.703 \\
C18:1n9 & $2.33 \pm 0.52^{\mathrm{b}}$ & $3.67 \pm 0.78^{\mathrm{ab}}$ & $7.28 \pm 1.33^{\mathrm{a}}$ & $4.89 \pm 1.80^{\mathrm{ab}}$ & 0.050 \\
C18:2n6c & $1.53 \pm 0.32^{\mathrm{b}}$ & $2.08 \pm 0.32^{\mathrm{b}}$ & $3.76 \pm 0.46^{\mathrm{a}}$ & $2.38 \pm 0.70^{\mathrm{ab}}$ & 0.023 \\
C18:3n3 & $0.12 \pm 0.03$ & $0.22 \pm 0.11$ & $0.66 \pm 0.22$ & $0.49 \pm 0.28$ & 0.181 \\
C20:3 & $0.05 \pm 0.01$ & $0.05 \pm 0.01$ & $0.05 \pm 0.01$ & $0.05 \pm 0.01$ & 0.993 \\
C20:4n6 & $0.57 \pm 0.12$ & $0.72 \pm 0.10$ & $0.60 \pm 0.07$ & $0.56 \pm 0.12$ & 0.664 \\
C22:0 & $0.05 \pm 0.01$ & $0.04 \pm 0.01$ & $0.05 \pm 0.01$ & $0.03 \pm 0.01$ & 0.694 \\
C22:6n3 & $1.19 \pm 0.27$ & $1.18 \pm 0.09$ & $1.12 \pm 0.12$ & $1.18 \pm 0.26$ & 0.994 \\
C24:0 & $0.06 \pm 0.01$ & $0.06 \pm 0.02$ & $0.09 \pm 0.01$ & $0.09 \pm 0.03$ & 0.557 \\
SFA & $4.51 \pm 0.97$ & $5.60 \pm 0.72$ & $8.15 \pm 0.92$ & $6.63 \pm 1.32$ & 0.081 \\
MUFA & $2.80 \pm 0.63$ & $7.27 \pm 2.53$ & $8.29 \pm 1.47$ & $5.85 \pm 1.96$ & 0.182 \\
PUFA & $3.46 \pm 0.74^{\mathrm{b}}$ & $4.25 \pm 0.49^{\mathrm{ab}}$ & $6.19 \pm 0.69^{\mathrm{a}}$ & $5.58 \pm 0.78^{\mathrm{a}}$ & 0.038 \\
PUFA / SFA & $0.77 \pm 0.01$ & $0.77 \pm 0.01$ & $0.78 \pm 0.08$ & $0.87 \pm 0.05$ & 0.434 \\
n-6 & $2.10 \pm 0.44^{\mathrm{b}}$ & $2.80 \pm 0.36^{\mathrm{b}}$ & $4.36 \pm 0.49^{\mathrm{a}}$ & $3.52 \pm 0.59^{\mathrm{ab}}$ & 0.016 \\
n-3 & $1.31 \pm 0.30$ & $1.40 \pm 0.13$ & $1.78 \pm 0.22$ & $2.00 \pm 0.20$ & 0.137 \\
Ratio n-6/n-3 & $1.63 \pm 0.07^{\mathrm{b}}$ & $1.97 \pm 0.10^{\mathrm{b}}$ & $2.48 \pm 0.21^{\mathrm{a}}$ & $1.72 \pm 0.12^{\mathrm{b}}$ & 0.002 \\
\hline
\end{tabular}

a,b: Means with different letters in the same line are different by Duncan's test $(\mathrm{p}<0.05)$.

a,b: Aynı satırda farklı harf taşıyan değerler Duncan testine göre farklıdır $(\mathrm{p}<0.05)$.

SFA: saturated fatty acid, MUFA: monounsaturated fatty acid, PUFA: polyunsaturated fatty acid; n-6: Omega-6 fatty acids; n-3: Omega-3 fatty acids; PUFA/SFA: Polyunsaturated:saturated ratio; n-6/n-3: Omega-6:omega-3 ratio; SE: Standard Error. FA composition expressed as percentage of total FA.

SFA: doymuş yağ asitleri, MUFA: tekli doymamış yağ asitleri, PUFA: çoklu doymamış yağ asitleri; n-6: Omega-6 yağ asitleri; n-3: Omega-3 yă̆ asitleri; PUFA/SFA: çoklu doymamış yağ asitleri: doymuş yağ asitleri oranı; n-6/n-3: Omega-6:omega-3 oranı; SE:Standart hata. FA toplam yağ asitlerinin yüzdesi olarak ifade edilmiştir. 
$(p<0.01)$. While the vitamin E concentration in the egg yolk of the group that consumed the vitamin $E$ supplemented diets was significantly higher, the vitamin A concentration of this group was found to be significantly low concentration compared to the other groups $(\mathrm{p}<0.05)$. There were no significant difference vitamin $\mathrm{D}_{2}$ and $\mathrm{D}_{3}$ levels among groups, and the highest stigmasterole level was found in the OLE-120 group $(\mathrm{p}<0.05)$.

The fatty acid levels in the egg yolk samples of the study groups are shown in Table 5. According to this table, the oleic acid (C18:1n9) levels in the control group, Group E, OLE-80 and OLE-120 groups were found to be $2.33,3.67,7.28$ and $4.89 \mu \mathrm{g} / \mathrm{g}$ respectively, and the control group was found to have lower values than the other groups $(\mathrm{p}<0.05)$. Levels of linoleic acid (C18:2n6c) were 1.53, 2.08, 3.76 and $2.38 \mu \mathrm{g} / \mathrm{g}$ respectively, where the levels in the OLE-80 and OLE120 groups were statistically higher than those of the remaining groups $(\mathrm{p}<0.05)$. No statistical difference was observed between groups regarding other fatty acid types $(p>0.05)$. While at the end of the study, no difference was observed between groups regarding saturated fatty acids (SFAs) or mono-unsaturated fatty acids (MUFAs), poly-unsaturated fatty acid (PUFA) and n-6 fatty acid levels were higher in the groups with OLE addition $(p<0.05)$. No difference was observed between groups regarding the levels of $n-3$ fatty acids, whereas the highest $n-6 / n-3$ ratio was observed in the OLE-80 group $(\mathrm{p}<0.01)$, and the remaining groups were found to be similar.

\section{Discussion and Conclusion}

Many researchers have reported that, herbal extract supplementation into the diets regulate animal digestion activity, increases the digestive juices that stimulate the appetite and food consumption of the animals, shows antibacterial effects, and prevents against diseases, and result in improvements in the performances of the animals $(13,24)$. The type of plants that these active substances are obtained from, the methods of extraction and their amount used in the feed mixes are important (7). This study investigated the effects of olive leaf extract, which had been comprehensively tested in the feed mixes of poultry animals before, on some blood parameters of these animals and on the nutritional substance ingredients of their eggs.

The serum glucose, cholesterol, triglyceride, HDL cholesterol, VLDL cholesterol and LDL cholesterol levels in the blood samples obtained at the end of the study revealed no statistical difference between groups. While Toptaş (28) reported no difference between groups with 50,100, 150 and 200 ppm OLE addition into the feed mixes of meat quail regarding HDL cholesterol and triglyceride, the $200 \mathrm{ppm}$ OLE added group was found to have lower total cholesterol than the other groups. Erener et al. (13) conducted a study with antibiotics, $200 \mathrm{ppm}$ vitamin $\mathrm{E}$, or 75, 150, 300 and 600 ppm OLE addition into the feed mixes of meat chickens, against a negative control group (0), and observed that the serum HDL and LDL cholesterol levels of the chickens in the control group were significantly lower than those of the other groups. Likewise, the groups with 150 and 600 ppm OLE addition showed lower total cholesterol levels as well. Our findings presented differences from those observed in the studies mentioned above. The serum glucose, cholesterol and triglyceride levels were expected to be lower in the groups with OLE addition. However, the results may be affected by many factors in animal studies such as the species of the animals, the properties of the ingredients and the physiological situation of the animals.

The eggs of poultry are important nutritional sources for humans. Additives such as zinc, selenium and poly unsaturated fatty acids in the feed mixes are commonly transmitted to the egg yolk thus nutritionally enriching the egg making them more appealing to consumers. An important criteria of this study was to determine the effects of OLE addition into feed mixes on the fatty acid and vitamin composition of the eggs. The egg yolk cholesterol levels observed in the groups at the end of the study were 10.43, 12.07, 13.10 and 13.28 $\mathrm{mg} / \mathrm{g}$. These findings show that adding vitamin $\mathrm{E}$ and OLE into feed mixes have significantly increased the cholesterol level of the eggs $(\mathrm{p}<0.01)$.

Da Silva et al. (11) have added 0, 1.5, 3.0 and 5.0\% flax seed oil into the diet of laying quail, and observed that the egg yolk cholesterol levels in the groups ranged between $8.56-10.99 \mathrm{mg} / \mathrm{g}$, and found that there was no significant difference between cholesterol levels and periods among the groups. The cholesterol levels observed in our study were similar to those observed in the study (11).

Filik (15) reported that $0,2,4$ and $8 \mathrm{~g} / \mathrm{kg}$ of dietary Ferula eleaochytris powder was supplemented into diet of laying hens, and the cholesterol levels observed in the group with $4 \mathrm{~g} / \mathrm{kg}$ addition were statistically lower than in other groups. Likewise, Kutlu et al. (18) added 90-120 $\mathrm{g} /$ tons Yucca schidigera extract into diet of laying hens, and determined that the cholesterol content of the eggs were reduced due to cholesterol and $\mathrm{NH}_{3}$ binding, and urease activity preventing the effects of steroidal saponin, which Yucca schidigera includes in high levels.

In present study, although the supplementation of olive leaf extract to diets did not affect vitamin A levels, the addition of vitamin $E$ decreased the levels $(p<0.05)$. 
Vitamin $\mathrm{E}$ addition into feed mixes significantly increases the level of vitamin $\mathrm{E}$ within the egg yolk $(p<0.001)$, whereas the vitamin E contents of OLE added groups and control group were similar $(\mathrm{p}>0.05)$.

The fatty acid composition of nutrients is important for healthy dietary intake in humans. It has been reported that diets rich in poly-unsaturated fatty acids are effective in the prevention of diseases such as diabetes, hypertension, vascular problems and myocardial infarction; by supporting the immune system some types of cancers may be prevented and geriatric problems such as dementia may be delayed $(19,23)$.

Unsaturated fatty acids found in vegetable oils such as LA and ALA are essential for human and animals, and must be consumed. The composition of dietary fats and fatty acid composition of poultry tissue and egg yolk are directly related because dietary fats in poultry undergo minimal change $(3,4,11)$.

Olive leaf extract addition into diets has increased the levels of $\mathrm{C} 18: 1 \mathrm{n} 9$ and $\mathrm{C} 18: 2 \mathrm{n} 6 \mathrm{c}$ fatty acids and subsequently, PUFA levels were increased as well $(\mathrm{p}<0.05)$ (Table 5). An important finding of the study was that the C18:1n9, C18:2n6c and n- 6 fatty acid levels $(\mathrm{p}<0.05)$, and the rate of $n-6 / n-3$ fatty acids in the 80 ppm OLE addition group was higher compared to other groups $(\mathrm{p}<0.01)$. There might be 3 possible explanations for this difference. First of all, levels of C18:2 n6 and C18:3 n3 fatty acids were relatively higher in the olive leaf extract that was used. Secondly, activity of the $\Delta-6$, $\Delta-5$ and $\Delta-4$ desaturase enzymes that synthesise more double-bounds might have increased at the $\Delta-6$ desaturation pathway. Finally the antioxidant effects of the phenolic compounds in the olive leaf extract might have resulted in the increased levels of PUFA.

The cholesterol levels within the egg yolk samples were increased in groups with olive leaf extract addition at the end of the study. Furthermore, vitamin E addition into the feed mixes significantly increased the level of vitamin $\mathrm{E}$ within the egg yolk.

The addition of $80 \mathrm{ppm}$ OLE into the feed mixes resulted in increases in the levels of egg yolk oleic acid (C18:1n9), linoleic acid (C18:2n6c) and PUFA where the differences were statistically significant. Similarly, while olive leaf extract addition into diets increased the levels of n-6 fatty acids, it had no effect on the level of n-3 fatty acids. The highest levels of $n-6 / n-3$ fatty acids were observed in the OLE-80 group.

\section{References}

1. Akçiçek E, Otleş S (2011): The Products of olive tree and health. National Olive Conference- Akhisar- Turkey. 163172.
2. AOAC (1995): Official Methods of analysis, $16^{\text {th }}$ ed. Association of Official Analytical Chemists Arlington, VA, 4.1-4.17.

3. Azman MA, Cerci IH, Birben N (2005): Effects of various dietary fat sources on performance and body fatty acid composition of broiler chickens. Tr J Vet Anim Sci, 29, 811-819.

4. Azman MA, Konar V, Seven PT (2004): Effects of different fat sources on performance and carcass fatty acid composition of broiler chickens. Rev Méd Vét, 155, 1-9.

5. Bao J, Zhang DW, Zhang JZ, Huang PL, Lee-Huang S (2007): Computational study of bindings of olive leaf extract (OLE) to HIV-1 fusion protein gp. 41 FEBS Lett, 581, 2737-2742.

6. Basmacioğlu-Malayoğlu B, Aktas B (2011): Antioxidant and antimicrobial activities of olive leaf and olive mill wastewater from olive oil processing by-products, Hayvansal Üretim Dergisi, 52, 49-58.

7. Basmacioğlu-Malayoğlu B, Altan O, Tüzmen MN, Yesıl-Celiktas O (2008): Effects of thymus and rosemary essential oils added into compound feed enriched by $n-3$ polyunsaturated fatty acids in laying hens on oxidative stability, lipid metabolism, performance and some egg quality criteria. TUBITAK, TOVAG-106O090 final report of the project. 125.

8. Biricik GF (2004): Composition of olive cultivars grown in economies of scale and suitability of process. University of Uludag Institute of Science, PhD Thesis (unpublished), 157. Bursa-Turkey.

9. Christie WW (1990): Gas Chromatography and Lipids. The Oil Press, Glaskow, 302.

10. Crampton EW, Maynard LA (1970): The relation of cellulose and lignin content to nutritive value of animal feeds. J Nutr, 15, 383-395.

11. Da Silva WA, Elias AHN, Aricetti JA, Sakamoto MI, Murakami AE, Gomes S T M, Visentainer J V, De Souza N E, Matsushita M (2009): Quail egg yolk (Coturnix coturnix japonica) enriched with omega-3 fatty acids. LWT - Food Sci and Tech, 42, 660-663.

12. Delgado-Pertinez M, Chesson A, Provan GJ, Garrido A, Gomez-Cabrera A (1998): Effect of different drying systems for the conservation of olive leaves on their nutritive value for ruminants. Ann Zootech, 47, 141-150.

13. Erener G, Ocak N, Oztürk E, Cankaya S, Özkanca R (2009): The Effects of olive leaf extract on performance, some blood parameters and cecal microflora of broilers. TUBITAK, TOVAG-1070820 final report of the project.

14. Esti M, Cinquanta L, La Notte E (1998): Phenolic compounds in different olive varieties. J Agric Food Chemistry, 46, 32 -35.

15. Filik G (2009): Rasyona ilave edilen çakşır (ferula eleaochytrıs) kökü tozunun yumurtacı tavuklarda yumurta verimi ve kalite özelliklerine etkileri. Yüksek Lisans Tezi, Çukurova Üniversitesi, Fen Bilimleri Enstitüsü. AdanaTurkiye.

16. Hara A, Radin NS (1978): Lipid extraction of tissues with a low-toxicity solvent, Analitical Biochemistry, 90, 420426. 
17. Keceli T (2000): Antimicrobial and antioxidant activity of olive oil phenolics in food science and technology. The University of Reading, 312.

18. Kutlu HR, Görgülü M, Unsal I (2001): Effects of dietary Yucca Schidigera powder on performance and egg cholesterol content of laying hens. J Appl Anim Res, 20, 49-56.

19. Lee OH, Lee BY (2010): Antioxidant and antimicrobial activities of individual and combined phenolics in Olea europaea leaf extract. Bioresour Technol, 101, 37513754.

20. Lee-Huang S, Huang PL, Zhang D, Lee JW, Bao J, Sun Y, Chang YT, Zhang J, Huang PL (2007): Discovery of small-molecule HIV-1 fusion and integrase inhibitors oleuropein and hydroxytyrosol. Part II. Integrase inhibition. Biochem Biophys Res Commun, 354, 879-884.

21. Lee-Huang S, Zhang L, Huang PL, Chang YT (2003): Anti-HIV activity of olive leaf extract (OLE) and modulation of host cell gene expression by HIV-1 infection and OLE treatment. Biochem Biophys Res Commun, 307, 1029- 1037.

22. Lopez-Cervantes L, Sanchez-Machado DI, RiosVazquez N J (2006): HPLC method for the simultaneous quantification of retinol, $\alpha$-tocopherol, and cholesterol in shrimp waste hydrolysate. Journal of Chromatography A, 1105, 135-139.

23. Owen RW, Giacosa A, Hull WE, Haubner R, Wurtele G, Spiegelhalder B, Bartsch H (2000): Olive oil consumption and health: the possible role of antioxidants. Lancet Oncol, 21, 107-112.

24. Pereira AP, Ferreira ICRF, Marcelino F, Valentao F, Andrade PB, Seabra R, Estevinho L, Bento A, Pereira JA (2007): Phenolic compounds and antimicrobial activity of olive (Olea europaea L. Cv. Cobrançosa) leaves. Molecules, 12, 1153- 1162.

25. Pirgun Y (2007): The Determination of the antioxidant activity of Gemlik and Halhal olives grown in Hatay. MSc Thesis, University of Cukurova, Institute of Science. Adana- Turkey.
26. Renis HE (1975): Inactivation of myxoviruses by calcium elenolate. Antimicrob. Agents Chemother, 8, 194-199.

27. Saija A, Trombetta D, Tomaino A, Cascio RLO, Princi P, Uccellabonina N F, Castelli F (1998): In-vitro evaluation of the antioxidant activity and biomembrane interaction of the plant phenols oleuropein and hydroxytyrosol. Int J Pharm 166,123-133.

28. Toptaş S (2010): The Effects of olive leaf exract supplementation to quail diets as natural antioxidant on the growth performance, fatty acid composition and lipid oxidation of meat, MSc Thesis, University of Gaziosmanpaşa, Institute of Science. Tokat-Turkey.

29. Tvrzicka E, Vecka M, Stankova B, Zak A (2002): Analysis of fatty acids in plasma lipoproteins by gas chromatography flame ionisation detection Quantative aspects. Anal Chimica Acta, 465, 337-350.

30. Vinha AF, Ferreres F, Silva BM, Valentao P, Goncalves A, Pereira JA, Oliveira MBPP, Seabra RM, Andrade PB (2005): Phenolic profiles of Portuguese olive fruits (Olea europaea L.): influence of cultivar and geographical origin. Food Chemistry, 89, 561-568.

31. Visioli F, Galli C (1995): Natural antioxidants and prevention of coronary heart disease: The potential role of olive oil and its minor constituents. Nutr Metab Cardovasc Dis, 5, 306-314.

Geliş tarihi: 09.07.2014/ Kabul tarihi: 20.02.2015
Address for correspondence:
Prof. Dr. Mehmet Ali Azman
University of Firat,
Faculty of Veterinary Medicine,
Department of Animal Nutrition and Nutritional Diseases,

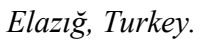
e-mail:mazman@firat.edu.tr 